\section{Weed Control Potential and Crop Safety of Selected Herbicides in Field-grown Cannas}

\author{
Russell W. Wallace ${ }^{1,2}$ and John C. Hodges ${ }^{1}$
}

\begin{abstract}
AdDitionAl INDEX wORDs. dimethenamid-p, flumioxazin, flumetsulam, halosulfuron, isoxaflutole, mesotrione, $s$-metolachlor, pendimethalin, sulfentrazone, trifloxysulfuron, Palmer amaranth, Amaranthus palmeri, yellow nutsedge, Cyperus esculentus, purple nutsedge, Cyperus rotundus, canna lily, Canna $\times$ generalis, 'Red President'

SUMMARY. Herbicides were applied pre-emergence (PRE) and early post-directed (EP-DIR) to determine their effects on crop injury and control of palmer amaranth (Amaranthus palmeri) and nutsedge (Cyperus spp.) in field-grown cannas (Canna $\times$ generalis). Results indicate that PRE-applied $s$-metolachlor + pendimethalin was the most effective treatment for controlling palmer amaranth. All other PRE-applied treatments failed to adequately control palmer amaranth. While moderate and temporary stunting was visible, in general, no herbicides (except trifloxysulfuron) significantly decreased canna rhizome yields. EP-DIR $s$-metolachlor or $s$-metolachlor + pendimethalin did not improve nutsedge control unless halosulfuron was included in the tank mixture. Addition of halosulfuron did not increase crop injury or decrease canna yields but did significantly reduce the number of nutsedge tubers found in the canna rhizomes at harvest. Results suggest that all PRE-applied herbicides tested were safe for cannas, but the lack of adequate palmer amaranth and nutsedge control prohibits their use as stand-alone herbicides for canna production in the midsouth. Post-directing applications of halosulfuron significantly improved nutsedge control and reduced tuber infestation and, therefore, should be included in all nutsedge management programs for canna rhizome production.
\end{abstract}

$\mathrm{F}$ ield production of cannas in the United States is difficult to estimate (Johnson et al., 1995), although in Texas it may be about 750 acres, primarily for rhizome seed stock production. Weed control in cannas and other ornamental crops is difficult due to an insufficient number of registered herbicides that provide soil residual (Collins et al., 2001). Herbicide use can be expensive compared with standard row crop production, and many herbicide registrations are limited to containerized crops and landscape use. Crop rotation can be a useful tool for integrated weed management, especially against perennial weeds like nutsedge (Warren and Coble, 1999). However, canna production is most successful on sandy soils, which are ideal for nutsedge growth, and rotation may be limited. Increased irrigation, required for good canna production, also reduces herbicide efficacy through leaching.

${ }^{1}$ Department of Horticultural Sciences, Texas A\&M University Research \& Extension Center, 1102 East FM 1294, Lubbock, Texas, 79403

${ }^{2}$ Corresponding author. E-mail: rwwallace@ag.tamu. edu employed to remove weeds manually at considerable cost.

Palmer amaranth is a troublesome and competitive broadleaf weed found in many commercial agronomic, vegetable, and ornamental field crops and is common throughout the midsouth and southern high plains of the U.S. (Bond and Oliver, 2006; Morgan et al., 2001). Palmer amaranth plants may grow over $1.0 \mathrm{~m}$ above crop canopies, shading crops and reducing their photosynthetic and reproductive capacities. Palmer amaranth may develop extremely thick stems and root systems weighing up to $5 \mathrm{~kg}$ each, causing significant problems during crop harvests (Keeley et al., 1987). Increasing resistance to dinitroaniline herbicides as well as the recent discovery of glyphosate resistance creates the need to find additional herbicides for use in weed management programs (Gossett et al., 1992; Scott and Smith, 2006).

Yellow nutsedge (Cyperus esculentus) and purple nutsedge (C. rotundus) continue to be serious problems in agronomic and nursery crops throughout the southern U.S., not only through weed competition but also through the infestation of tubers in products sold (Beste and Frank, 1990; Collins et al., 2001; Webster and Coble, 1997). Nutsedge tubers may be disseminated to homeowners through retailers or to other grower fields. When found in the fields, canna growers regularly handpick nutsedge tubers before selling the crop, significantly reducing their profits. Currently, halosulfuron offers fair to good control of nutsedge with post-emergence applications (McDaniel et al., 1999) and has potential for use in large-scale commercial production.

Two herbicides currently registered for nursery production are $s$-metolachlor and pendimethalin. However, commercial growers are in need of additional herbicides that control adapting weed species or that have longer soil residual (Collins

\begin{tabular}{lllc}
\hline $\begin{array}{l}\text { Units } \\
\text { To convert U.S. to SI, } \\
\text { multiply by }\end{array}$ & U.S. unit & SI unit & $\begin{array}{l}\text { To convert SI to U.S., } \\
\text { multiply by }\end{array}$ \\
\hline 0.4047 & $\mathrm{acre}(\mathrm{s})$ & $\mathrm{ha}$ & $2.471 \mathrm{l}$ \\
0.3048 & $\mathrm{ft}$ & $\mathrm{m}$ & 3.2808 \\
0.0929 & $\mathrm{ft}{ }^{2}$ & $\mathrm{~m}^{2}$ & 10.7639 \\
9.3540 & $\mathrm{gal} / \mathrm{acre}$ & $\mathrm{L}^{2} \mathrm{ha}^{-1}$ & 0.1069 \\
2.54 & inch(es) & $\mathrm{cm}$ & 0.3937 \\
0.4536 & $\mathrm{lb}$ & $\mathrm{kg}$ & 2.2046 \\
1.1209 & $\mathrm{lb} / \mathrm{acre}$ & $\mathrm{kg} \cdot \mathrm{ha}^{-1}$ & 0.8922 \\
6.8948 & $\mathrm{psi}$ & $\mathrm{kPa}$ & 0.1450
\end{tabular}


et al., 2001; Gossett et al., 1992). Although $s$-metolachlor and pendimethalin provide fair to good control of perennial and annual weeds (Richardson and Zandstra, 2006), cultivation and hand-weeding are still required, and this combination offers only fair control of nutsedge. Past research has concentrated on weed control for containerized or landscape ornamentals, but little research has been conducted for large-scale commercial field-grown production. Therefore, research was initiated to determine crop safety and weed control potential of selected herbicides for control of palmer amaranth and nutsedge under field-grown conditions for canna rhizome production.

\section{Materials and methods}

Test SITE. Trials were conducted in 2003 and 2004 at a field set aside for research located on a commercial farm near Plainview in the Texas Panhandle. The test area was planted to wheat (Triticum aestivum) as a cover crop the previous fall, a common practice in the area to reduce soil erosion by wind. The soil type was an Amarillo fine sandy loam (fine-loamy, mixed, superactive, thermic Aridic Paleustalfs) with a $7.2 \mathrm{pH}$ and $2.0 \%$ organic matter. 'Red President' canna rhizomes were planted following standard grower practices and were mechanically transplanted on 23 Apr. 2003 and on 21 Apr. 2004. About $10 \mathrm{~d}$ following transplanting and before canna shoot emergence, the wheat was killed with glyphosate. A natural population of palmer amaranth existed within the test area; however, in Winter 2003 the site was over-sown with yellow nutsedge and purple nutsedge tubers and disked into the soil profile.

Experimental Design. Test plots consisted of two rows of cannas spaced 40 inches between-rows and 12 inches within-rows for a seeding rate of 13,000 cannas/acre. Preemergence herbicide treatments were applied $24 \mathrm{~h}$ after transplanting to plots measuring $6.7 \times 30 \mathrm{ft}$. Herbicides were applied using a carbon dioxide-charged backpack sprayer and hand-held boom equipped with four 8002 Tee Jet nozzles (Spraying Systems Co., Wheaton, Ill.) calibrated to spray $20 \mathrm{gal} / \mathrm{acre}$ at $35 \mathrm{psi}$. Early post-directed sprays were applied at the equivalent pressure and rate but with a two-nozzle hand-held hooded sprayer, with sprays directed at the base of the cannas. The test site was monitored for optimum canna growth, including fertility, irrigation, and pest control. All plots were cultivated once during the season $\approx 8$ weeks following planting.

Percent weed control and crop injury ratings were recorded 6 and 10 weeks after herbicide treatment (WAT) in both years. The entire test area was hand-weeded 2 weeks following the final weed control rating to remove large in-row weeds and allow for herbicide responses on the canna rhizomes. Canna rhizomes were machine-harvested and weighed on 8 Dec. 2003 and 10 Jan. 2005 for the 2003 and 2004 trials, respectively.

Pre-emergence herbicide treatments consisted of an untreated control, a hand-weeded control (handweeded three times during season), and eight herbicide treatments including $s$-metolachlor + pendimethalin (grower standard) and experimental treatments of dimethenamid-p, flumioxazin, flumetsulam, isoxaflutole, mesotrione, sulfentrazone, and trifloxysulfuron. In 2004, a second trial evaluated PRE-applied $s$-metolachlor in combination with pendimethalin followed by EP-DIR halosulfuron with or without $s$-metolachlor + pendimethalin. In that trial, nutsedge shoots were counted in $0.25-\mathrm{m}^{2}$ quadrats placed randomly within each plot. At harvest, nutsedge tubers adhering to the canna rhizomes were collected, separated by species (yellow

Table 1. Effect of pre-emergence herbicide treatments on crop injury (\%) in field-grown 'Red President' cannas.

\begin{tabular}{|c|c|c|c|c|c|}
\hline \multirow[b]{3}{*}{ Treatments } & \multirow{3}{*}{$\begin{array}{c}\text { Rate } \\
\left(\mathrm{kg} \cdot \mathrm{ha}^{-1} \text { a.i. }\right)^{\mathrm{z}}\end{array}$} & \multicolumn{4}{|c|}{ Stunting $(\%)^{\mathrm{y}}$} \\
\hline & & \multicolumn{2}{|c|}{2003} & \multicolumn{2}{|c|}{2004} \\
\hline & & 6 WAT $^{x}$ & $10 \mathrm{WAT}$ & $6 \mathrm{WAT}$ & $10 \mathrm{WA} \mathrm{T}$ \\
\hline Untreated & Season-long & $0 \mathrm{c}$ & $0 \mathrm{~b}$ & $0 \mathrm{a}$ & $0 \mathrm{a}$ \\
\hline Hand-weeded & $\begin{array}{l}\text { Three times } \\
\text { during season }\end{array}$ & $0 \mathrm{c}$ & $0 \mathrm{~b}$ & $0 \mathrm{a}$ & $0 \mathrm{a}$ \\
\hline $\begin{array}{l}s \text {-Metolachlor }+ \\
\text { pendimethalin }\end{array}$ & $2.13+4.43$ & $0 \mathrm{c}$ & $0 \mathrm{~b}$ & $10 \mathrm{a}$ & $4 \mathrm{a}$ \\
\hline Dimethenamid-p & 0.74 & $18 \mathrm{ab}$ & $6 \mathrm{ab}$ & $0 \mathrm{a}$ & $15 \mathrm{a}$ \\
\hline Mesotrione & 0.21 & $9 \mathrm{bc}$ & $4 \mathrm{ab}$ & $3 a$ & $5 \mathrm{a}$ \\
\hline Sulfentrazone & 0.16 & $5 \mathrm{bc}$ & $4 \mathrm{ab}$ & $3 a$ & $5 \mathrm{a}$ \\
\hline Isoxaflutole & 0.11 & $6 \mathrm{bc}$ & $13 \mathrm{ab}$ & $8 \mathrm{a}$ & $8 \mathrm{a}$ \\
\hline Flumioxazin & 0.07 & $6 \mathrm{bc}$ & $3 \mathrm{ab}$ & $5 \mathrm{a}$ & $3 \mathrm{a}$ \\
\hline Flumetsulam & 0.06 & $34 \mathrm{a}$ & $18 \mathrm{a}$ & $10 \mathrm{a}$ & $13 \mathrm{a}$ \\
\hline
\end{tabular}

${ }^{\mathrm{z}} 1 \mathrm{~kg} \cdot \mathrm{ha}^{-1}=0.8922 \mathrm{lb} /$ acre

${ }^{y}$ Means within columns followed by the same letter are not significantly different at the $5 \%$ level according to Fisher's protected least significant difference.

${ }^{x}$ WAT, weeks after treatment. nutsedge or purple nutsedge), and counted.

Data analysis. Trials were designed as randomized complete blocks with four replications per treatment. Data were subjected to analysis of variance and means separated using Fisher's protected least significant difference at the 5\% level. Percentage data were arcsine-transformed before analyses to stabilize variances; however, non-transformed data are reported.

\section{Results and discussion}

Seasonal environments. Temperatures and precipitation recorded near the trials (Texas A\&M University Research \& Extension Center at Halfway) differed between the two growing seasons. In 2003, the average soil and air temperatures recorded during the growing season were $2 \%$ and $4 \%$ higher, respectively, compared with 2004. However, annual precipitation only totaled 8.7 inches in 2003 (51\% below seasonal average), while in 2004 it was 30 inches (40\% above seasonal average). Although supplemental irrigation was applied as-needed, differences in seasonal temperatures and rainfall likely influenced weed populations (germination and growth), herbicide efficacy, and canna growth in this study.

Pre-emergence herbicide EFFECTS ON CROP INJURY. Percentage of crop injury (stunting) evaluated 6 and 10 weeks after herbicide treatment (WAT) differed between years; 
Table 2. Effect of pre-emergence herbicide treatments on palmer amaranth control (\%) in field-grown 'Red President' cannas.

\begin{tabular}{|c|c|c|c|c|c|}
\hline \multirow[b]{3}{*}{ Treatments } & \multirow{3}{*}{$\begin{array}{c}\text { Rate } \\
\left({\left.\mathrm{kg} \cdot \mathrm{ha} \mathrm{a}^{-1} \text { a.i. }\right)^{\mathrm{z}}}\right.\end{array}$} & \multicolumn{4}{|c|}{ Palmer amaranth control $(\%)^{y}$} \\
\hline & & \multicolumn{2}{|c|}{2003} & \multicolumn{2}{|c|}{2004} \\
\hline & & 6 WAT $^{x}$ & $10 \mathrm{WAT}$ & $6 \mathrm{WAT}$ & $10 \mathrm{WAT}$ \\
\hline Untreated & Season-long & $0 \mathrm{c}$ & $0 \mathrm{e}$ & $0 \mathrm{e}$ & $0 \mathrm{~d}$ \\
\hline Hand-weeded & $\begin{array}{l}\text { Three times } \\
\text { during season }\end{array}$ & 99 a & 99 a & 99 a & 99 a \\
\hline $\begin{array}{l}s \text {-Metolachlor }+ \\
\text { pendimethalin }\end{array}$ & $2.13+4.43$ & $92 \mathrm{a}$ & $80 \mathrm{ab}$ & $95 \mathrm{ab}$ & $94 \mathrm{abc}$ \\
\hline Dimethenamid-p & 0.74 & $90 \mathrm{a}$ & $43 \mathrm{bcd}$ & $58 \mathrm{~cd}$ & $95 \mathrm{ab}$ \\
\hline Mesotrione & 0.21 & $45 \mathrm{~b}$ & $50 \mathrm{bcd}$ & $36 \mathrm{~d}$ & 87 bc \\
\hline Sulfentrazone & 0.16 & $60 \mathrm{ab}$ & 39 cde & $45 \mathrm{~cd}$ & $91 \mathrm{abc}$ \\
\hline Isoxaflutole & 0.11 & $87 \mathrm{a}$ & $66 \mathrm{abc}$ & $77 \mathrm{abc}$ & $83 \mathrm{c}$ \\
\hline Flumioxazin & 0.07 & $41 \mathrm{~b}$ & $23 \mathrm{de}$ & $59 \mathrm{bcd}$ & $90 \mathrm{abc}$ \\
\hline Flumetsulam & 0.06 & $90 \mathrm{a}$ & 56 bcd & $80 \mathrm{abc}$ & $94 \mathrm{ab}$ \\
\hline
\end{tabular}

${ }^{\mathrm{z}} \mathrm{l} \mathrm{kg} \cdot \mathrm{ha}^{-1}=0.8922 \mathrm{lb} /$ acre.

${ }^{y}$ Means within columns followed by the same letter are not significantly different at the $5 \%$ level according to Fisher's protected least significant difference.

${ }^{x}$ WAT, weeks after treatment.

therefore, data are presented separately (Table 1). PRE- applied trifloxysulfuron caused significant canna injury $(76 \%)$ in 2003 (data not shown); therefore, this herbicide was dropped from the trial in 2004.

In both years, crop injury was $10 \%$ or less with PRE-applied $s$-metolachlor + pendimethalin at either rating. Similarly, mesotrione, sulfentrazone, isoxaflutole, and flumioxazin showed less than $13 \%$ injury at both ratings and were not different from the grower standard or hand-weeded control plots. Although stunting did not occur with mesotrione, there was temporary bleaching of the emerging leaves. Mesotrione is a carotenoidinhibiting herbicide, and these symptoms were temporarily present in treated

Table 3. Effect of pre-emergence herbicide treatments on nutsedge control (\%) in field-grown 'Red President' cannas in 2004.

\begin{tabular}{|c|c|c|c|}
\hline \multirow[b]{2}{*}{ Treatments } & \multirow{2}{*}{$\begin{array}{c}\text { Rate } \\
\left(\mathrm{kg} \cdot \mathrm{ha}^{-1} \text { a.i. }\right)^{\mathrm{z}} \\
\end{array}$} & \multicolumn{2}{|c|}{ Nutsedge control $(\%)^{\mathrm{y}}$} \\
\hline & & 6 WAT $^{x}$ & $10 \mathrm{WAT}$ \\
\hline Untreated & Season-long & $0 \mathrm{c}$ & $0 \mathrm{c}$ \\
\hline Hand-weeded & $\begin{array}{l}\text { Three times } \\
\text { during season }\end{array}$ & $95.5 \mathrm{a}$ & $99.0 \mathrm{a}$ \\
\hline $\begin{array}{l}s \text {-Metolachlor }+ \\
\text { pendimethalin }\end{array}$ & $2.13+4.43$ & $77.5 \mathrm{ab}$ & $42.5 \mathrm{~b}$ \\
\hline Dimethenamid-p & 0.74 & $51.3 \mathrm{~b}$ & $10.0 \mathrm{bc}$ \\
\hline Mesotrione & 0.21 & $42.5 \mathrm{bc}$ & $17.5 \mathrm{bc}$ \\
\hline Sulfentrazone & 0.16 & $51.3 \mathrm{~b}$ & $16.3 \mathrm{bc}$ \\
\hline Isoxaflutole & 0.11 & $48.8 \mathrm{~b}$ & $0 \mathrm{c}$ \\
\hline Flumioxazin & 0.07 & $58.8 \mathrm{ab}$ & $0 \mathrm{c}$ \\
\hline Flumetsulam & 0.06 & $63.8 \mathrm{ab}$ & $0 \mathrm{c}$ \\
\hline
\end{tabular}

${ }^{\mathrm{z}} 1 \mathrm{~kg} \cdot \mathrm{ha}^{-1}=0.8922 \mathrm{lb} /$ acre.

${ }^{y}$ Means within columns followed by the same letter are not significantly different at the $5 \%$ level according to Fisher's protected least significant difference.

'WAT, weeks after treatment.

cannas (Vencill, 2002). Crop injury was observed with treatments of flumetsulam $(34 \%)$ and dimethenamid$\mathrm{p}(18 \%)$ in 2003; however, in 2004 , injury was reduced and not different from control plots. Crop injury differences between the two seasons may be a response to the different precipitation levels that occurred in 2003 and 2004.

Pre-emergence herbicide EFFECTS ON WEED CONTROL. Weeds evaluated included palmer amaranth in 2003 and palmer amaranth plus yellow nutsedge and purple nutsedge in 2004. Control of palmer amaranth was generally poor to good in both years depending on herbicide treatment (Table 2). Dimethenamid-p, isoxaflutole, and flumetsulam gave equivalent control 6 WAT compared with $s$-metolachlor + pendimethalin in 2003 , although by 10 WAT control decreased greatly. Mesotrione, sulfentrazone, and flumioxazin gave poor control of palmer amaranth 6 WAT, and control continued to decrease by 10 WAT.

In 2004, all herbicide treatments except $s$-metolachlor + pendimethalin gave poor control of palmer amaranth by 6 WAT. At 10 WAT and following a single cultivation, weed control in all herbicide treatments increased. This is opposite the weed control response that was observed in 2003.

In 2004, $s$-metolachlor + pendimethalin gave poor to fair control of nutsedge (combined visual assessment) at both 6 and 10 WAT (Table 3). Although $s$-metolachlor + pendimethalin gave the best control $(78 \%)$ at 6 WAT, it was not different from all other herbicide treatments. All herbicide treatments except mesotrione were significantly different from the untreated control. By 10 WAT, all herbicides including $s$-metolachlor + pendimethalin had less than $45 \%$ nutsedge control. These results suggest that even the current standard herbicide program for cannas (PRE-applied $s$-metolachlor + pendimethalin) is inadequate to control nutsedge, and other options are needed.

Pre-emergence herbicide EFFECTS ON CANNA YIELDS. Moderate crop injury and early to midseason competition from palmer amaranth did not decrease canna rhizome yields during 2003 (Table 4). Although nonsignificant, the highest yields were found in cannas treated with flumetsulam, mesotrione, and isoxaflutole. Lower yields were recorded in the hand-weeded control and dimethenamid-p treatments.

In 2004, canna rhizome yields were $320 \%$ lower when compared with those in 2003. Although not reflected in the weed control ratings, weeds present during 2004 grew at a faster rate and were considerably larger and more competitive within the canna plots. This likely resulted in overall decreased yields during that year.

Results from the pre-emergence trial suggest that the herbicides tested can be considered relatively safe for use on field-grown cannas. However, control of palmer amaranth will likely be inconsistent with changing seasonal conditions. During relatively 
Table 4. Effect of pre-emergence herbicide treatments on rhizome yield in field-grown 'Red President' cannas.

\begin{tabular}{|c|c|c|c|}
\hline \multirow[b]{2}{*}{ Treatments } & \multirow{2}{*}{$\begin{array}{c}\text { Rate } \\
\left(\mathrm{kg} \mathrm{ha}^{-1} \text { a.i. }\right)^{\mathrm{z}}\end{array}$} & \multicolumn{2}{|c|}{$\begin{array}{c}\text { Canna rhizome yield } \\
\qquad\left(\mathrm{kg} \mathrm{ha}^{-1}\right)^{\mathrm{y}}\end{array}$} \\
\hline & & 2003 & 2004 \\
\hline Untreated & Season-long & $15,141 \mathrm{a}$ & $5,595 \mathrm{ab}$ \\
\hline Hand-weeded & $\begin{array}{l}\text { Three times } \\
\text { during season }\end{array}$ & $10,386 \mathrm{a}$ & $5,972 \mathrm{ab}$ \\
\hline $\begin{array}{l}s \text {-Metolachlor }+ \\
\text { pendimethalin }\end{array}$ & $2.13+4.43$ & $15,269 \mathrm{a}$ & $7,752 \mathrm{a}$ \\
\hline Dimethenamid-p & 0.74 & $11,319 \mathrm{a}$ & $1,980 \mathrm{~b}$ \\
\hline Mesotrione & 0.21 & 17,646 a & $3,551 \mathrm{ab}$ \\
\hline Sulfentrazone & 0.16 & $15,827 \mathrm{a}$ & $4,889 \mathrm{ab}$ \\
\hline Isoxaflutole & 0.11 & $17,033 \mathrm{a}$ & $5,461 \mathrm{ab}$ \\
\hline Flumioxazin & 0.07 & $14,574 \mathrm{a}$ & $3,908 \mathrm{ab}$ \\
\hline Flumetsulam & 0.06 & $18,606 \mathrm{a}$ & $3,564 \mathrm{ab}$ \\
\hline
\end{tabular}

${ }^{2} 1 \mathrm{~kg} \mathrm{ha}^{-1}=0.8922 \mathrm{lb} /$ acre

yeans within columns followed by the same letter are not significantly different at the $5 \%$ level according to Fisher's protected least significant difference.

dry years, Palmer amaranth growth may be reduced by herbicides plus low soil moisture, but during seasons of high moisture, weed pressure may increase and significantly reduce canna yields. No herbicides evaluated in 2004 gave sufficient control of nutsedge to be considered for future testing.

EARLY POST - EMERGENCE HERBICIDE EFFECTS ON NUTSEDGE CONTROL AND CANNA YIELD. A study was conducted in 2004 to evaluate PRE-applied $s$-metolachlor or $s$-metolachlor + pendimethalin in combination with EP-DIR halosulfuron for control of yellow nutsedge and purple nutsedge tuber production (Table 5).
Late-season (22 Sept.) ratings indicated that PRE-applied $s$-metolachlor or $s$-metolachlor + pendimethalin did not significantly reduce the number of nutsedge shoots per square meter when compared with the untreated control. Similarly, hand-weeding nutsedge failed to significantly reduce shoot numbers.

When s-metolachlor or $s$-metolachlor + pendimethalin were tank-mixed with halosulfuron and applied EP-DIR, the number of nutsedge shoots decreased compared with the untreated control, as well as when only $s$-metolachlor was applied PRE. $s$-Metolachlor + pendimethalin decreased shoot numbers by $57 \%$, but a second application including halosulfuron further decreased shoot numbers to $75 \%$ of the untreated control.

Regardless of herbicide treatment, canna rhizome yields were not significantly different from the handweeded or untreated controls (Table $5)$. Where herbicides were applied, average yields increased $19 \%$ and $14 \%$, respectively, when compared with the untreated and hand-weeded controls. These results suggest that herbicide applications improved yields by reducing weed populations, although under these conditions significantly better weed control would be needed to further increase canna yields.

The presence of nutsedge tubers in the final canna product reduces quality and potentially spreads nutsedge to non-infested fields. Removing tubers from the rhizomes is critical but tedious and costly. In this study, hand-weeding or PRE-applied $s$-metolachlor or $s$-metolachlor + pendimethalin failed to significantly reduce the numbers of yellow nutsedge tubers per hectare (Table 5). When halosulfuron was applied EP-DIR in combination with $s$-metolachlor or $s$-metolachlor + pendimethalin, yellow nutsedge tuber production significantly decreased $64 \%$ and $80 \%$, respectively, compared with the untreated and hand-weeded controls.

The average number of purple nutsedge tubers recovered from

Table 5. Effect of selected herbicide treatments on yellow and purple nutsedge growth and yield of field-grown 'Red President' cannas in 2004.

\begin{tabular}{|c|c|c|c|c|c|c|c|}
\hline Treatment & $\begin{array}{c}\text { Rate } \\
\left(\mathrm{kg} \cdot \mathrm{ha}^{-1} \text { a.i. }\right)^{\mathrm{z}} \\
\end{array}$ & Timing & $\begin{array}{l}\text { Late-season } \\
\text { nutsedge } \\
\text { shoots } \\
\left(\text { no. } / \mathrm{m}^{2}\right)^{\mathrm{z}} \\
\end{array}$ & $\begin{array}{c}\text { Canna } \\
\text { yields } \\
\left(\mathrm{kg} \cdot \mathrm{ha}^{-1}\right)^{\mathrm{z}}\end{array}$ & $\begin{array}{c}\text { Yellow } \\
\text { nutsedge } \\
\text { tubers } \\
(\text { no. } / \text { ha })^{\mathrm{z}} \\
\end{array}$ & $\begin{array}{c}\text { Purple } \\
\text { nutsedge } \\
\text { tubers } \\
(\text { no. } / \text { ha })^{z}\end{array}$ & $\begin{array}{l}\text { Nutsedge- } \\
\text { infested canna } \\
\text { (tubers } / \mathrm{kg} \\
\text { rhizomes) }\end{array}$ \\
\hline Untreated & & Season-long & $16.8 \mathrm{a}^{\mathrm{y}}$ & $5,595 \mathrm{a}$ & $7,465 \mathrm{ab}$ & $67,584 \mathrm{ab}$ & $23.9 \mathrm{ab}$ \\
\hline Hand weeded & & $\begin{array}{l}\text { Three times } \\
\text { during season }\end{array}$ & $11.5 \mathrm{ab}$ & 5,972 a & $13,113 \mathrm{a}$ & $105,713 \mathrm{a}$ & $30.3 \mathrm{a}$ \\
\hline pendimethalin & $2.13+4.43$ & PRE & $7.3 \mathrm{ab}$ & $7,752 \mathrm{a}$ & $6,254 \mathrm{ab}$ & $41,761 \mathrm{~b}$ & $7.9 \mathrm{~b}$ \\
\hline $\begin{array}{l}s \text {-Metolachlor }+ \\
\text { pendimethalin }+ \\
\text { halosulfuron }\end{array}$ & $2.13+4.43+0.05$ & PRE EP-DIR & $4.5 \mathrm{~b}$ & $6,460 \mathrm{a}$ & $1,816 \mathrm{~b}$ & $14,324 \mathrm{~b}$ & $4.3 \mathrm{~b}$ \\
\hline $\begin{array}{l}s \text {-Metolachlor }+ \\
\text { pendimethalin }+ \\
s \text {-metolachlor }+ \\
\text { pendimethalin }+ \\
\text { halosulfuron }\end{array}$ & $\begin{array}{l}2.13+4.43+2.13+ \\
\quad 4.43+0.05\end{array}$ & PRE EP-DIR & $3.8 \mathrm{~b}$ & $7,208 \mathrm{a}$ & $3,632 \mathrm{~b}$ & $20,571 \mathrm{~b}$ & $3.1 \mathrm{~b}$ \\
\hline
\end{tabular}

${ }^{\mathrm{z}} \mathrm{l} \mathrm{kg} \cdot \mathrm{ha}^{-1}=0.8922 \mathrm{lb} /$ acre, 1 shoot $/ \mathrm{m}^{2}=0.0929 \mathrm{shoot} / \mathrm{ft}^{2}, \mathrm{l}$ tuber $/$ ha $=0.4047 \mathrm{tuber} / \mathrm{acre}, 1$ tuber $/ \mathrm{kg}=0.4536$ tuber $/ \mathrm{lb}$.

${ }^{y}$ Means within columns followed by the same letter are not significantly different at the $5 \%$ level according to Fisher's protected least significant difference. 
canna rhizomes was 6.6 times greater than that of yellow nutsedge (Table 5 ). Herbicide treatments significantly reduced purple nutsedge tuber numbers compared with the hand-weeded control. Although nonsignificant, the number of purple nutsedge tubers averaged across herbicide treatments was $56 \%$ less compared with the untreated control. Similarly, within herbicide treatments, adding halosulfuron to the tank-mix reduced purple nutsedge tubers an average of $59 \%$ more than herbicide treatments without halosulfuron.

Interestingly, both yellow nutsedge and purple nutsedge tuber production was $43 \%$ and $36 \%$ higher, respectively, in hand-weeded treatments compared with the untreated control. This response suggests that hand-weeding nutsedge shoots during the season may actually stimulate tuber production. This evidence would suggest that herbicides are essential for adequate nutsedge control in field-grown cannas and that hand-weeding may increase tuber production within production fields (Labrada et al., 1983).

Combining the numbers of nutsedge tubers infesting harvested canna rhizomes showed that the greatest numbers were found in the untreated and hand-weeded controls. Although not different from untreated plots, all herbicide treatments, except $s$-metolachlor applied alone, were lower than the handweeded control. Where halosulfuron was added to the EP-DIR sprays, the number of nutsedge tubers harvested decreased by $57 \%$.

\section{Conclusion}

The results of this research suggest that PRE applications of $s$-metolachlor + pendimethalin remain the most effective herbicide treatment for controlling palmer amaranth, though control is not season-long. All other PRE-applied herbicides failed to adequately control palmer amaranth under the conditions of this study. Although minor foliar crop injury was visible, most PRE-applied herbicides (except trifloxysulfuron) did not decrease yields. The results also indicate that, to significantly reduce yellow nutsedge or purple nutsedge tuber production, and thus decrease hand-removal at harvest, a second application of post-directed herbicides including halosulfuron is required. Post-directed halosulfuron did not increase crop injury or decrease canna yields, but did significantly reduce the number of nutsedge tubers found in the harvested canna rhizomes. More research is needed to determine optimal rates and timings for halosulfuron and other herbicides with nutsedge activity for use in canna production fields.

\section{Literature cited}

Beste, C.E. and J.R. Frank. 1990. Influence of metolachlor on Ilex crenata Thunb. for control of yellow nutsedge. J. Environ. Hort. 8:58-60.

Bond, J.A. and L.R. Oliver. 2006. Comparative growth of palmer amaranth (Amaranthus palmeri) accessions. Weed Sci. 54:121-126.

Collins, K.B., R.E. McNeil, and L.A. Weston. 2001. Evaluation of sulfentrazone for weed control and phytotoxicity in field-grown landscape plants. J. Environ. Hort. 19:189-194.

Gossett, B.J., E.C. Murdock, and J.E. Toler. 1992. Resistance of palmer amaranth to dinitroaniline herbicides. Weed Technol. 6:587-591.

Johnson, D., J. Harwood, and G. Zepp. 1995. Field-grown bulb crops: An economic assessment of the feasibility of providing multiple-peril crop insurance.
Econ. Res. Serv., U.S. Dept. Agr., Washington, D.C.

Keeley, P.E., C.H. Carter, and R.J. Thullen. 1987. Influence of planting date on growth of palmer amaranth (Amaranthus palmeri). Weed Sci. 35: 199-204.

Labrada, R.E., E. Paredes, and R. Muniz. 1983. Weed competition in a cucumber crop. Trop. Pest Mgt. 29:52-55.

McDaniel, G.L., D.C. Fare, W.T. Witte, and P.C. Flanagan. 1999. Yellow nutsedge control and nursery crop tolerance with Manage as affected by adjuvant choice. J. Environ. Hort. 17:114-119.

Morgan, G.D., P.A. Baumann, and J.M. Chandler. 2001. Competitive impact of palmer amaranth (Amaranthus palmeri) on cotton (Gossypium hirsutum) development and yield. Weed Technol. 15:408-412.

Nowacki, W. 1983. Influence of weed infestation of the potato crop on the efficiency of potato lifter and mechanical damage of tubers (English summary). Biul. Inst. Ziem. 29:93-100.

Richardson, R.J. and B.H. Zandstra. 2006. Evaluation of flumioxazin and other herbicides for weed control in gladiolus. Weed Technol. 20:394-398.

Scott, R.C. and K. Smith. 2006. Prevention and control of glyphosate-resistant pigweed in Roundup Ready ${ }^{\mathrm{TM}}$ soybean and cotton. Univ. of Arkansas, Coop. Ext. Serv. Fact Sheet FSA2152.

Vencill, W.K. (ed.). 2002. Herbicide handbook. 8th ed. Weed Sci. Soc. Amer., Lawrence, Kans.

Warren, L.S. and H.D. Coble. 1999. Managing purple nutsedge (Cyperus rotundus) populations utilizing herbicide strategies and crop rotation sequences. Weed Technol. 13:494-503.

Webster, T.M. and H.D. Coble. 1997. Changes in the weed species composition of the southern United States: 1974 to 1995. Weed Technol. 11:308-317. 